Article

\title{
Photovoltaic Characteristics of Multiwalled Carbon Nanotube Counter-Electrode Materials for Dye-Sensitized Solar Cells Produced by Chemical Treatment and Addition of Dispersant
}

\author{
Sedong Kim ${ }^{1}{ }^{\oplus}$, Otgonbayar Dovjuu ${ }^{1}$, Soon-Ho Choi ${ }^{2}{ }^{\oplus}$, Hyomin Jeong ${ }^{2}{ }^{\circledR}$ and Ji-Tae Park ${ }^{3, *}$ \\ 1 Department of Energy and Mechanical Engineering, Graduate School, Gyeongsang National University, \\ Cheondaegukchi-Gil 38, Tongyeong 53064, Korea; sdkim@gnu.ac.kr (S.K.); \\ otgonbayar1109@gmail.com (O.D.) \\ 2 Department of Energy and Mechanical Engineering, Institute of Marine Industry, Gyeongsang National \\ University, Cheondaegukchi-Gil 38, Tongyeong 53064, Korea; choi_s_h@naver.com (S.-H.C.); \\ hmjeong@gnu.ac.kr (H.J.) \\ 3 Training Ship Operation Center, College of Marine Science, Gyeongsang National University, \\ Cheondaegukchi-Gil 38, Tongyeong 53064, Korea \\ * Correspondence: parkjit@daum.net
}

Received: 20 February 2019; Accepted: 12 April 2019; Published: 15 April 2019

\begin{abstract}
Multiwalled carbon nanotubes (MWCNTs) have excellent electrical conductivity and good chemical stability, and are used as counter electrodes in dye-sensitized solar cells (DSSCs). The counter electrodes collect electrons from the external circuit and catalyze the redox reaction in the electrolyte. Electrocatalysis is an important step for generating energy from triiodide reduction in DSSCs. In this study, chemically treated MWCNTs were investigated for improving the photovoltaic performance of DSSCs. The MWCNTs were modified through chemical oxidation with sulfuric acid/nitric acid $\left(\mathrm{H}_{2} \mathrm{SO}_{4} / \mathrm{HNO}_{3}\right)$ or potassium persulfate/sodium hydroxide $\left(\mathrm{K}_{2} \mathrm{~S}_{2} \mathrm{O}_{8} / \mathrm{NaOH}\right)$. Nanocellulose $(\mathrm{CNC})$ was used as a dispersant to improve the photovoltaic performance and dispersibility as an alternative material for counter electrodes in DSSCs. The counter electrodes were prepared on fluorine-doped tin oxide (FTO) glass substrates by spin coating nanofluids. Morphological and structural investigations were performed using scanning transmission electron microscopy (TEM), Fourier-transform infrared (FTIR) spectroscopy, and Raman spectroscopy. The electrical conductivity and UV light absorption of the DSSCs were analyzed to evaluate their photovoltaic performance. The results of these analyses showed that chemical functionalization and addition of CNC were effective for increasing the electrical conductivity and UV light absorption. Finally, all result trends were the same. Increasing the dispersibility of the counter electrode was found to improve the reduction of $\mathrm{I}_{3}{ }^{-}$at the interface between the MWCNTs and the electrolyte, thereby, improving the energy conversion efficiency.
\end{abstract}

Keywords: multiwalled carbon nanotube (MWCNT); dye-sensitized solar cell (DSSC); chemical treatment; nanocellulose dispersion; electrocatalysis

\section{Introduction}

Dye-sensitized solar cells (DSSCs) have attracted considerable attention owing to their high efficiency, simple fabrication process, and low production cost [1-3]. DSSCs contain a sensitizing dye, a transparent conducting substrate, nanometer-sized $\mathrm{TiO}_{2}$ film, an iodide electrolyte, and counter electrode [4]. Improved DSSC efficiency can provide enormous economic advantages [5-9]. The counter electrode is a significant constituent component of the DSSCs, serving an indispensable 
role in collecting electrons [10]. Pt and Pt-based metallic structures are commonly used as counter electrodes because of their high electrochemical activity. However, $\mathrm{Pt}$ is relatively scarce and its use as a counter-electrode in DSSCs is limited by its high cost and potential toxicity and purity issues. Therefore, better alternatives are necessary for the triiodide reduction in DSSCs. Congiu et al. [11] reported that $\mathrm{p}$-DSCs with a CoS anode has an external quantum efficiency very similar to that obtained with anodes consisting of Pr and fluorine-doped tin oxide (FTO). Moreover, p-DSC employing ERY (erythrosine)-sensitized $\mathrm{NiO}$ as a photoactive cathode and a $\mathrm{CoS}$ anode has a conversion efficiency of $0.026 \%$ similar to that obtained with Pt-FTO anodes ( $0.030 \%)$. Zhang et al. [12] investigated efficient and transparent polymers for dye-sensitized solar cells. They found that the polymer made from a mixed acetonitrile-dichloromethane solvent showed enhanced catalytic activity for redox reactions compared with that from a single solvent.

Multiwalled carbon nanotubes (MWCNTs) [13-15], graphenes [16-23], metals or metal nanowires [24,25], and hybrids of these [26,27] are emerging as potential alternatives, owing to their large surface areas.

Ma et al. [28] found that (Fe-Co)-CNFs had high electrocatalytic activity for the $\mathrm{I}_{3}{ }^{-} / \mathrm{I}^{-}$redox couple. These can be used as high-efficiency and low-cost counter electrodes for DSSCs which means the graphite characteristics of fibers make them electronically conducting. MWCNTs have rapid electron-transfer kinetics, a large surface area, and are capable of electrocatalytic activity for triiodide reduction, which are some of its advantages over $\mathrm{Pt}[29,30]$. Moreover, many studies have investigated the stability and safety of electrolytes [31,32]. Nguyen et al. [33] found a cost effective and eco-friendly electrolyte solvent mixture for dye-sensitized solar cells. Its performance in cells was initially less efficient than comparison solvents, but became more stable than the others after more than $1000 \mathrm{~h}$. MWCNTs, when treated with solutions such as nitric acid, sulfuric acid, potassium permanganate, potassium persulfate, ammonium hydroxide, and hydrogen peroxide, can act as improved electrical conducting layers $[34,35]$. Lee et al. investigated the electrochemical characteristics of DSSC with MWCNT electrodes and it was revealed that a cell conversion efficiency, a short-circuited current density, and an open-circuit voltage can be better with containing MWCNTs [36]. Datsyuk et al. [34] studied the effect of oxidation on the structural integrity of MWCNTs, through acidic (using nitric acid, sulfuric acid/hydrogen peroxide) and basic (using ammonium hydroxide/hydrogen peroxide) treatments. They found that the oxidized structures of MWCNTs exhibited better dispersion characteristics, compared to the pristine MWCNT structures. Park et al. [37] investigated the effects of chemical treatment of carbon nanotubes (CNTs) on the dispersion stability and electrical conductivity of CNT/polyaniline. Owing to the major advantages of MWCNTs, various approaches have been developed for fabricating MWCNT counter electrodes, such as screen printing [38], spray drying [39], printing/coating using doctor blades [40], and chemical vapor deposition [41]. Moreover, cellulose is the most abundant polymer in nature. There have been many reports on the development of cellulose-based materials over the years. Cellulose nanocrystals (CNCs) have become widely used in many studies [42,43]. These are rod-shaped nanoparticles obtained from the acid hydrolysis of cellulose. They are approximately 10 to $100 \mathrm{~nm}$ in diameter and 100 to $1000 \mathrm{~nm}$ in length, depending on the hydrolysis conditions and the cellulose source. CNCs strongly interact with water through hydrogen bonding owing to the hydroxyl groups on the cellulose molecule. In this work, we investigated efficient DSSCs containing treated MWCNTs fabricated through wet grinding in a planetary ball-milling machine, those with CNC used as a dispersant, and their hybrid composites with novel synergistic properties, as alternatives to $\mathrm{Pt}$, for counter electrodes for electrocatalytic triiodide reduction. The counter electrodes were deposited as porous films on FTO-coated glass using spin coating. The performance of several carbon-coated samples was compared to evaluate the performance improvements caused by chemical treatment and use of dispersant. 


\section{Experimental Details}

\subsection{Preparation of Materials}

Distilled water (DW) produced by a membrane-type DW maker, which maintained the water quality to under $10 \mathrm{ppm}$ of total dissolved solids, was used in the experiments. Pristine MWCNTs approximately $20 \mathrm{~nm}$ in diameter and $5 \mu \mathrm{m}$ in length, with purity greater than $95 \%$ and impurities less than 3\% (Carbon Nanomaterial Technology Co., Ltd., Seoul, Korea) were used. The CNC used in this research was extracted from the western hemlock plant, and was supplied by SKB Tech., Seoul, Korea. Nitric acid $\left(\mathrm{HNO}_{3}\right)$ at a concentration of $63 \%$ (Junsei Chemicals Co., Ltd., Tokyo, Japan), sulfuric acid $\left(\mathrm{H}_{2} \mathrm{SO}_{4}\right)$ at a concentration of $98 \%$ (Junsei Chemicals Co., Ltd., Tokyo, Japan), potassium persulfate $\left(\mathrm{K}_{2} \mathrm{~S}_{2} \mathrm{O}_{8}\right)$ with greater than $99.0 \%$ purity (Sigma-Aldrich Co., Ltd., Hamburg, Germany), and sodium hydroxide $(\mathrm{NaOH})$ with greater than $97.0 \%$ purity (Junsei Chemicals Co., Ltd., Tokyo, Japan) were used in the treatment processes.

\subsection{Surface Modification of MWCNTs}

In order to increase the specific surface area, flattening and fine planetary ball milling (Haji Engineering, Seoul, Korea) was performed. It should be noted that this grinding method is an effective way to increase the surface area, and thereby, significantly reduce the agglomeration of the MWCNTs [44]. Spherical zirconia balls $(3.0 \mathrm{~mm})$ were used as the collision medium. The samples were treated at a grinding speed of $500 \mathrm{rpm}$ under wet conditions for $1 \mathrm{~h}$. The grinding method is specified elsewhere $[45,46]$. The functionalized MWCNTs were prepared using two different treatment methods, namely acidic treatment and basic treatment. For acidic treatment, the surface modification of MWCNTs was performed using a mixture of concentrated nitric acid $\left(\mathrm{HNO}_{3}\right)$ and sulfuric acid $\left(\mathrm{H}_{2} \mathrm{SO}_{4}\right)$ in a 1:3 volume ratio. Pristine MWCNTs were suspended in the acid mixture, and ultrasonication (1510E-DTH, Branson Ultrasonic Corporation 41, Danbury, CT, USA) was performed at $25^{\circ} \mathrm{C}$. Next, oxidation was performed at $100{ }^{\circ} \mathrm{C}$ for $100 \mathrm{~min}$ on a magnetic stirrer (hot plate stirrer, SMSH-20A, Scilab Korea, Co., Ltd., Seoul, Korea). The sample was then filtered and rinsed with DW until the pH value reached 7.0, after which, it was dried in a furnace [46]. The sample treated with $\mathrm{H}_{2} \mathrm{SO}_{4} / \mathrm{HNO}_{3}$ was designated as A-CNT. For basic treatment, surface modification of MWCNTs was performed using potassium persulfate $\left(\mathrm{K}_{2} \mathrm{~S}_{2} \mathrm{O}_{8}\right)$. The pristine MWCNTs and DW were added to a flask and dispersed in an ultrasonic bath. Then, $\mathrm{K}_{2} \mathrm{~S}_{2} \mathrm{O}_{8}$ was added to the flask and the $\mathrm{pH}$ of the reaction system was adjusted to 13 by adding concentrated $\mathrm{NaOH}$ solution. The flask, equipped with a reflux condenser and a magnetic stir plate, was kept at $85^{\circ} \mathrm{C}$ after mixing for $2 \mathrm{~h}$, and was then cooled down to room temperature. The contents of the flask were separated using a membrane filter and rinsed with DW until the $\mathrm{pH}$ reached 7.0. Finally, the functionalized MWCNTs were dried in a furnace [47]. The sample treated with $\mathrm{K}_{2} \mathrm{~S}_{2} \mathrm{O}_{8} / \mathrm{NaOH}$ was designated as $\mathrm{K}-\mathrm{CNT}$. The resulting products were used to prepare the purified and ground MWCNTs. The step in fabricating effective DSSCs using MWCNT counter electrodes is to disperse MWCNTs in a base. For enhanced dispersion, all the previously prepared structures were dispersed ultrasonically in ethanol solution for $40 \mathrm{~min}$. The concentrations of the MWCNTs in ethanol were $0.5 \mathrm{wt} \%$. The various types of samples used as the counter electrodes and their experimental parameters are shown in Figure 1. 


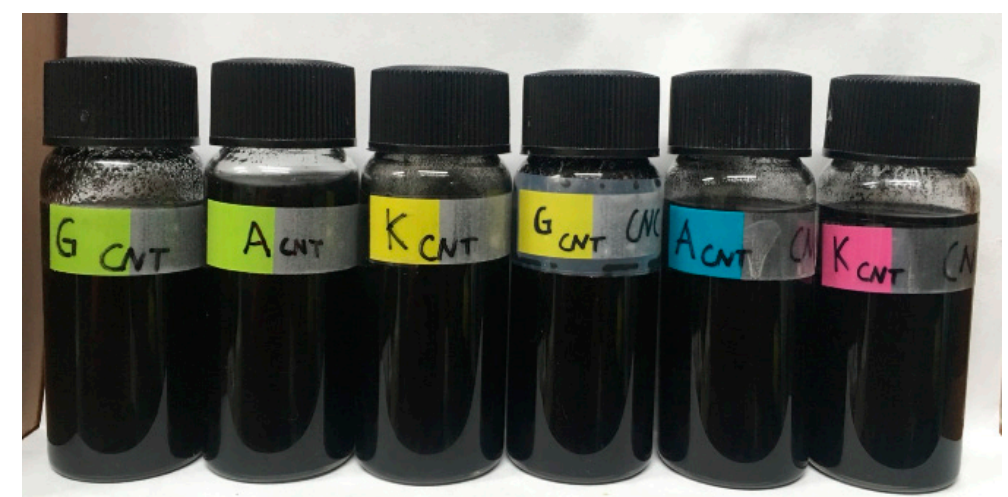

(a)

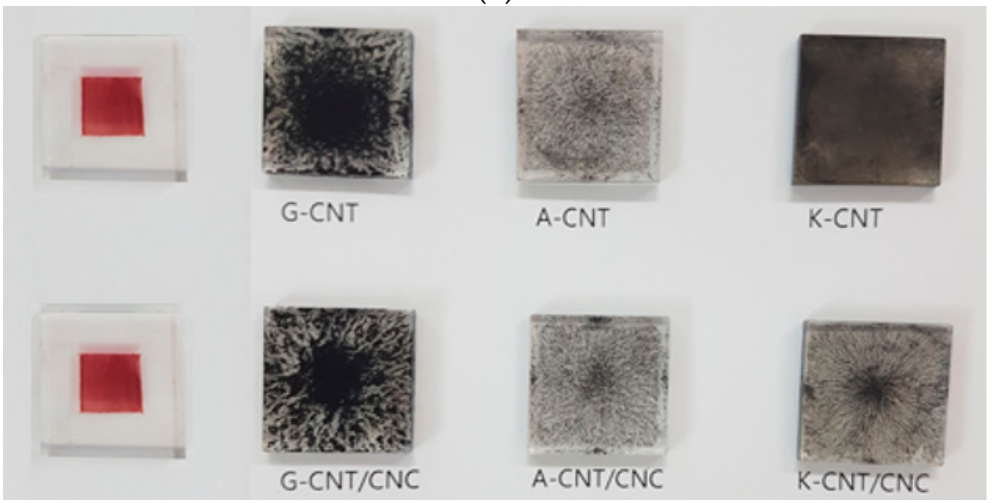

(b)

Figure 1. Photos of the sample (Ground CNT, A-Ground CNT, K-Ground CNT, Ground CNT/CNC, A-Ground CNT/CNC, K-Ground CNT/CNC): (a) Photo of the solution samples, (b) $\mathrm{TiO}_{2}$ electrode and each coated nanoparticle FTO glass.

\subsection{Counter Electrode Fabrication}

Before deposition, the FTO glass (Solaronix, Aubonne, Switzerland, $8 \Omega / \mathrm{sq}$ ) was ultrasonically treated in ethanol, acetone, and DW-15 min for each step-to remove some contaminants like the organic pollutants. then, the spin-coating process is used for the prepared samples on the cleaned FTO glass at a velocity of $2000 \mathrm{rpm}$ for $25 \mathrm{~s}$ at $25{ }^{\circ} \mathrm{C}$. To evaporate the ethyl cellulose and terpineol, the temperature of deposited MWCNTs films should be higher than $400{ }^{\circ} \mathrm{C}$ [48], which would cause the MWCNTs films to peel easily from the substrate. Therefore, an annealing temperature of $350{ }^{\circ} \mathrm{C}$ was used to prepare the MWCNTs counter electrodes. The fully prepared MWCNTs films on FTO were found to be suitable for use as counter electrodes.

\section{4. $\mathrm{TiO}_{2}$ Working Electrode and DSSC Fabrication}

$\mathrm{TiO}_{2}$ photoanodes have been investigated in studies [49,50]. In this experiment, they were used to compare the effects of the different counter electrodes. First, the $\mathrm{TiO}_{2}$ (average powder size $20 \mathrm{~nm}, \mathrm{P} 25$ of Degussa) colloid in ethanol was mixed with terpineol and a solution of ethyl cellulose in ethanol. The details of the fabrication procedure for the $\mathrm{TiO}_{2}$ photoanodes have been given elsewhere [51]. Using the screen-printing technique, the prepared $\mathrm{TiO}_{2}$ working electrodes were fabricated on FTO glass with an approximate thickness of 8 to $10 \mu \mathrm{m}$ and surface area of $1.0 \times 1.0 \mathrm{~cm}^{2}$. The coated $\mathrm{TiO}_{2}$ electrodes were calcined at $500{ }^{\circ} \mathrm{C}$ for $1 \mathrm{~h}$ in air to obtain an anatase $\mathrm{TiO}_{2}$ phase. After, it was sintered to $150^{\circ} \mathrm{C}$ for $30 \mathrm{~min}$. Then, the $\mathrm{TiO}_{2}$ working electrodes were immersed in a $0.3 \mathrm{mM}$ solution of a Ru complex dye (cis-bis (isothiocyanato) bis (2,2-bipyridyl-4,4-dicarboxylato)-ruthenium (II) bis-tetrabutylammonium, (N719); Solaronix, Aubonne, Switzerland) in anhydrous ethanol for $24 \mathrm{~h}$ to make that the dye molecules were fully covered. The dye-impregnated $\mathrm{TiO}_{2}$ electrodes were assembled with the previous produced counter electrodes. A Surlyn polymer foil gasket (60 $\mu \mathrm{m}$ thickness) was 
used as a spacer-cum-sealant between the electrodes. The electrolyte, iodolyte AN-50 (iodide-based redox electrolyte, Solaronix, Aubonne, Switzerland), was injected into the cell via vacuum filling, through the hole on the counter-electrode side. Finally, Surlyn and a microscopic glass cover were sealed with the electrolyte injection hole [48]. For all the measurements, tests were recorded within three days and each was carried out three times in the same way. However, no significant difference was found in any experiment.

\subsection{Characterization}

Transmission electron microscopy (TEM) (JEM-2100F, JEOL, Tokyo, Japan) was used for the morphological analysis. The structural characteristics were analyzed using a FTIR (Bruker (VERTEX $80 \mathrm{v})$, Billerica, MA, USA) spectroscope with spectral range between 500 and $4000 \mathrm{~cm}^{-1}$. A Raman spectrophotometer with spectral range between 1000 and $2000 \mathrm{~cm}^{-1}$ (VERTEX 80v series, Bruker Co., Ltd., Hong Kong, China) was used to reveal the effects of the chemical treatment of MWCNT. The absorbance of the samples was measured using a UV-visible spectrophotometer (X-ma 3000 Series Spectrophotometer, Human Co., Ltd., Chungcheongbuk-do, Korea) operating at wavelengths ranging from 190 to $1190 \mathrm{~nm}$. The electrical conductivity meter (Model CM-25R, DKK-TOA Co., Ltd, Tokyo, Japan) measured and compared the conductivity of each sample. The photocurrent-voltage characteristics of the DSSCs were conducted under simulated solar illumination of constant light intensity $\left(100 \mathrm{~mW} / \mathrm{cm}^{2}\right)$, the light of which was made of a $150 \mathrm{~W}$ xenon lamp. The insolation intensity of the irradiated light was measured by a solar simulator, PEC-L01 (Peccell, Technologies Co., Yokohama, Japan).

\section{Results and Discussion}

\subsection{Morphological Surface Analysis of MWCNTs}

Figure 2 presents the TEM images showing the morphological characteristics of three different MWCNTs treated with chemical oxidation. The images show that the pristine MWCNTs contained large amounts of impurities such as catalyst residues, amorphous carbon, and other forms of impurities (arrows in Figure 2A). The catalyst particles were evidently embedded evidently in the tips or tube cores of the MWCNTs [52]. The impurities were removed from the MWCNTs, and the nanotube tips were opened after the treatment processes, which can be clearly observed in Figure 2B,C. The morphologies and tubular structures of the MWCNTs observed in Figure 2B,C illustrated that the structures of the MWCNTs did not deteriorate after the treatment processes.
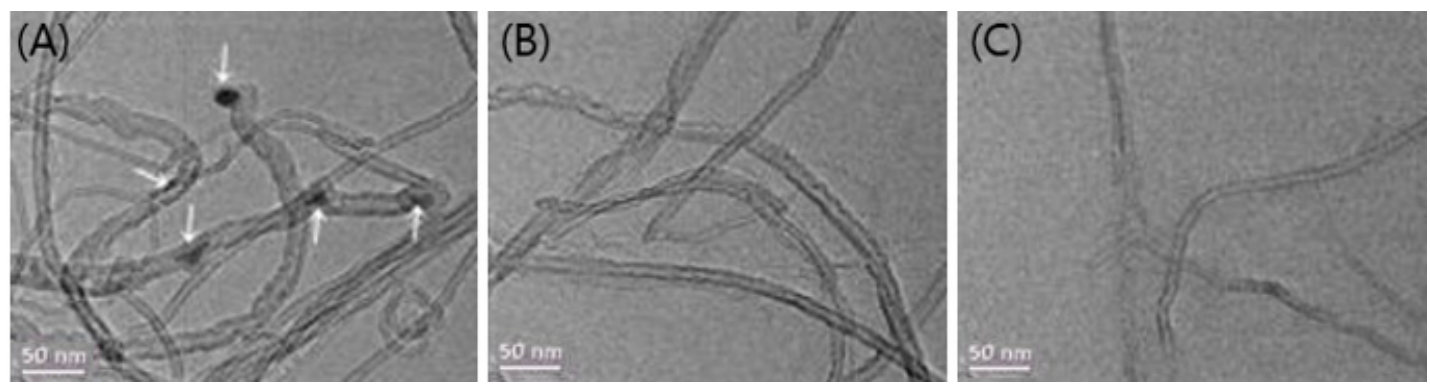

Figure 2. TEM images of the pristine and surface modified MWCNTs: (A) Pristine CNT, (B) A-CNT, (C) K-CNT.

The functional group confirmation was provided by the results of the Raman spectroscopy and FTIR spectroscopy. Raman spectroscopy has historically played an important role in analyzing structural characteristics such as for assessing the quality and structural defects of graphitic materials. It has also become a useful tool for understanding the behaviors of electrons and phonons in graphene, aiming at obtaining a better understanding of the information about graphene that can be obtained 
from Raman spectroscopy studies [53-56]. As shown in Figure 3, the D and G main peaks of the pristine and surface-modified MWCNTs were observed around 1350 and $1580 \mathrm{~cm}^{-1}$ in the Raman spectra of all composites. The $\mathrm{D}$ band indicates the ill-organized graphitic structure with structural defects and $\mathrm{sp}^{3}$ hybridized carbons, whereas the $\mathrm{G}$ band indicates the tangential $\mathrm{C}=\mathrm{C}$ stretching and the vibrations due to the integrity of the hexagonal $\mathrm{sp}^{2}$ hybridization carbon [57]. After treatment, the intensity of the D band was increased, compared to that of the pristine MWCNTs, in all cases, which reveal that $\mathrm{sp}^{3}$ hybridized carbons were generated as the functional groups and were attached to the surfaces of the MWCNTs. The intensity ratio between the $D$ and the $G$ bands $\left(I_{D} / I_{G}\right)$ indicates the extent of functionalization [58]. The intensity ratio $\left(I_{\mathrm{D}} / I_{\mathrm{G}}\right)$ was increased for all surface-modified structures of MWCNTs. It can be seen that the functional groups are successfully assembled on the surfaces of the MWCNTs and that structural changes have occurred.

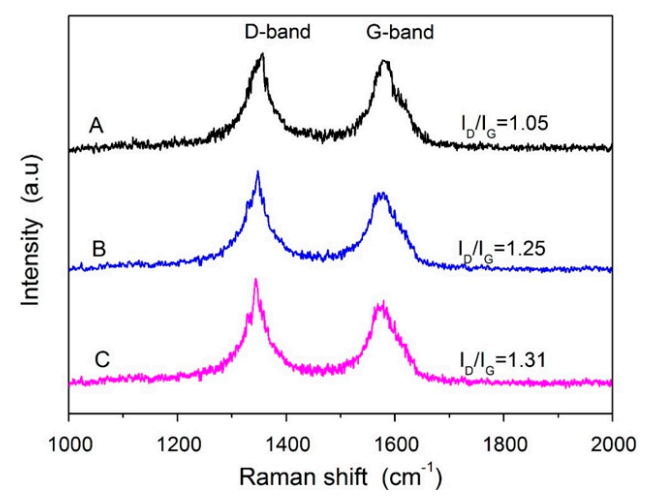

Figure 3. Raman spectra of pristine and surface modified MWCNTs: (A) Pristine CNT, (B) A-CNT, (C) K-CNT.

FTIR is used mainly as a qualitative technique for the evaluation of a functional group. Figure 4 shows the FTIR spectra of the pristine MWCNTs and the surface-modified MWCNTs produced by the two different methods. As shown in Figure 3, the trends of the FTIR spectra were similar; the intensities of the peaks are different because of the different chemical treatments, which offered similar oxygen functional groups.

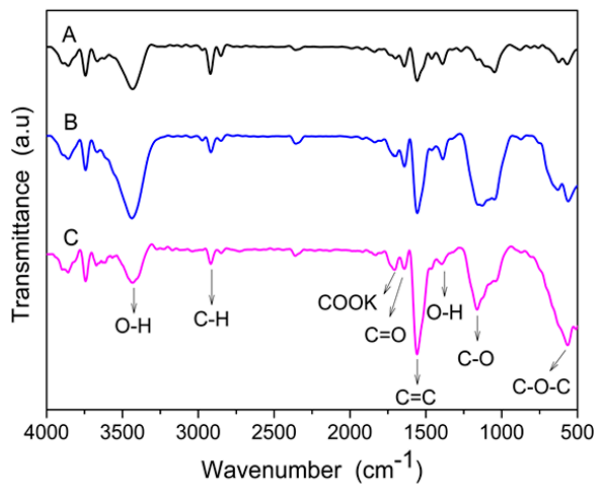

Figure 4. FTIR spectra of pristine and surface modified MWCNTs: (A) Pristine CNT, (B) A-CNT, (C) K-CNT.

The peaks around $3430 \mathrm{~cm}^{-1}$ could be attributed to the vibration of $\mathrm{O}-\mathrm{H}$ in the hydroxyl and carboxyl groups formed after the surface treatment processes $[59,60]$. For A-CNT, the O-H stretching intensity was stronger than that in K-CNT. Potassium persulfate was used as an oxidant for basic treatment, and therefore, COOK functional groups were attached to the surfaces of the CNTs. Therefore, the O-H stretching intensity was decreased slightly for K-CNTs, compared to A-CNTs. The bands around $2800-2900 \mathrm{~cm}^{-1}$ were caused by the $\mathrm{C}-\mathrm{H}$ asymmetric and symmetric stretching vibrations, 
derived from a long alkyl chain [61]. The absorption peak around $1715 \mathrm{~cm}^{-1}$ corresponds to the COOK from the carboxylic groups. The $\mathrm{C}=\mathrm{O}$ group characteristic peak was also observed around $1635 \mathrm{~cm}^{-1}$ and could be assigned to the carbonyl group from quinine or the ring structure [62], which showed a low intensity in all structures of MWCNTs. Appearance of a peak around $1550 \mathrm{~cm}^{-1}$ indicates the existence of carbon double bonding $(C=C)$, which reveals the structure of pristine MWCNTs [63], and the peak intensity was increased in all structures of modified MWCNTs. It is possible to attribute this increase in the peak intensity to the fact that impurities such as amorphous carbon were completely removed from the surface of MWCNTs after the treatment processes. The peaks around $1100 \mathrm{~cm}^{-1}$ correspond to the $\mathrm{C}-\mathrm{O}$ stretching mode of the carboxylic acid group, and had strong intensity in each modified structure of MWCNTs. These peaks indicate successful generation of oxygen functional groups on the MWCNTs. All these results show that the functional groups were assembled successfully on the surfaces of the MWCNTs and that the structure had been changed.

\subsection{Material Dispersion and Light Absorption}

Generally, the dispersion characteristics of nanofluids are investigated by UV-absorption spectra [64]. Higher absorbance values mean enhanced dispersion of CNTs in the solution. All of the CNTs are active in the UV-visible region and show characteristic bands that correspond to additional absorption because of the 1D van Hove singularities $[65,66]$. To obtain the light absorption and dispersion characteristics of the materials, the previously produced samples were investigated using a UV spectrometer. Figure 5 shows the dispersions of all the sample solutions that were used for coating. Contrastingly, the UV light absorbance values of the treated CNTs were higher than those of the untreated CNTs, in the solutions. Therefore, it could be inferred that the purification of the CNTs removed the impurities and agglomeration of materials, thereby creating a solution with good dispersion. The solution with CNC indicated a higher value of UV light absorbance than the solution without CNC. These findings showed that chemical functionalization and addition of CNC could improve the dispersion of CNTs in a solution significantly. The dispersion state results were in good agreement with the UV light absorption measurement results.

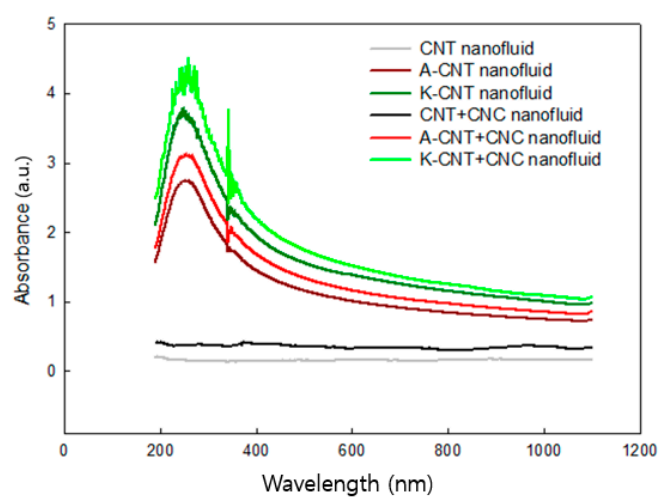

Figure 5. Absorbance measurements of the pristine MWCNTs, surface modified MWCNTs, and surface modified MWCNTs with CNC.

\subsection{Electrical Conductivity}

Electrical conductivity is a unique property in the fields of electromechanical devices and microelectronics. In this study, the electrical conductivity of fluids with different MWCNT structures was investigated. Calibration was performed with standard potassium chloride $(1.41,12.86 \mu \mathrm{S} / \mathrm{cm})$ solutions before the measurement. Figure 6 shows the electrical conductivity of fluids with $0.1 \mathrm{wt} \%$ concentration of pristine MWCNTs, surface-modified MWCNT structures, and with CNC based on DW. The electrical conductivity of the surface-modified MWCNT nanofluids was higher than that of the pristine MWCNT nanofluids, and the electrical conductivity of the surface-modified MWCNTs with CNC was higher than that of the other modified MWCNTs. CNC can play a significant role 
in improving the dispersion; therefore, it should be noted that the agglomeration of nanoparticles in the base fluid is an important factor that may affect the electrical conductivity. The chemical functionalization significantly reduced the agglomeration of MWCNTs, thereby increasing the electrical conductivity [67]. The electrical conductivity of the pristine MWCNT nanofluid with a concentration of $0.1 \mathrm{wt} \%$ was enhanced from 16.3 to $26.8,94.7,182.7,190.6$, and $210.0 \mu \mathrm{S} / \mathrm{cm}$ for A-CNT, K-CNT, $\mathrm{CNT}+\mathrm{CNC}$, A-CNT $+\mathrm{CNC}$, and $\mathrm{K}-\mathrm{CNT}+\mathrm{CNC}$, respectively, at a temperature of $25^{\circ} \mathrm{C}$. The highest electrical conductivity was obtained for K-CNT $+\mathrm{CNC}$. Therefore, alkaline treatment and addition of $\mathrm{CNC}$ can be considered an effective method for increasing electrical conductivity.

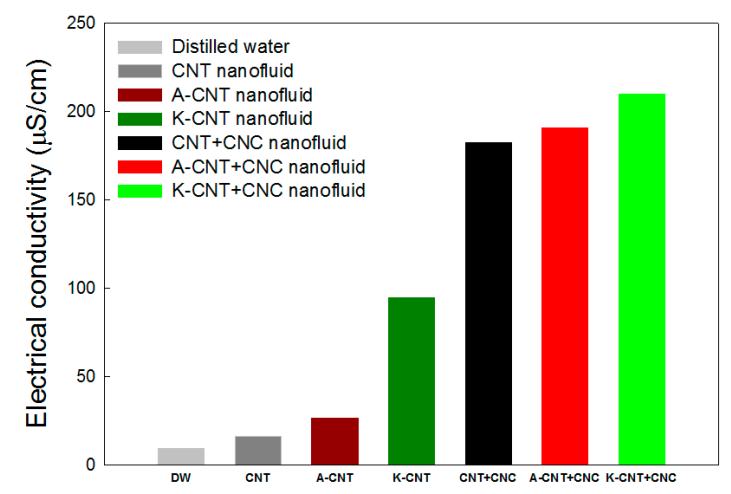

Figure 6. Electrical conductivity of pristine MWCNTs, surface modified MWCNTs, and surface modified MWCNTs with CNC.

\subsection{DSSC Photovoltaic Performance}

The electrical conductivity measurements, TEM images, and UV light absorption results showed that the photovoltaic performance of the DSSCs with chemically functionalized CNTs and CNC materials as counter electrodes was higher than that of the untreated CNTs. Figure 7 compares the photocurrent-voltage characteristics ( $J-V$ curve) of MWCNTs with different counter electrodes. The open-circuit photovoltage $\left(V_{\mathrm{oc}}\right)$, short-circuit photocurrent $\left(\mathrm{J}_{\mathrm{sc}}\right)$, fill factor $(\mathrm{FF})$, and energy conversion efficiency $(\eta)$ of DSSCs with various counter electrodes are summarized in Table 1. These results show that the photovoltaic performance characteristics of the DSSCs prepared using treated CNTs are significantly superior to those of the DSSCs with untreated CNT counter electrodes. Furthermore, the energy conversion efficiency values of all DSSCs are improved after adding materials, as shown in Table 1. The enhancement of photovoltaic performance with CNT counter electrodes could be assumed to have resulted from the following process. The introduction of treated MWCNTs provides more active surface sites for adsorbing dye molecules, which harvests fast redox kinetics owing to greater photo-induced electron density. The increased dispersion of the counter electrodes could promote the $\mathrm{I}_{3}{ }^{-}$reduction at the interface between the MWCNTs and electrolyte, thereby improving the energy conversion efficiency.

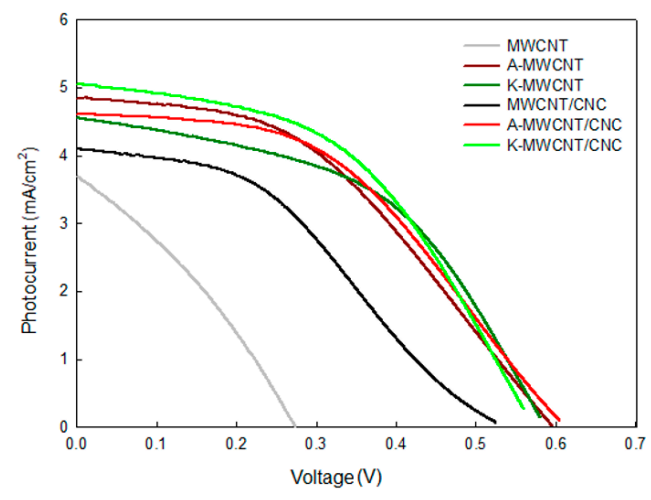

Figure 7. Photocurrent-voltage $(J-V)$ curve characteristics of the DSSCs with various counter electrodes. 
Table 1. Photocurrent-voltage $(J-V)$ curve characteristics of dye-sensitized solar cells (DSSCs) with various counter electrodes

\begin{tabular}{ccccc}
\hline Counter Electrode & $J_{\text {sc }}\left(\mathbf{m A} / \mathbf{c m}^{-2}\right)$ & $V_{\text {oc }}(\mathbf{V})$ & FF & $\eta(\mathbf{\%})$ \\
\hline CNT & 3.684 & 0.2738 & 0.3172 & 0.2051 \\
A-CNT & 5.066 & 0.5794 & 0.413 & 1.214 \\
K-CNT & 4.48 & 0.5796 & 0.4877 & 1.266 \\
CNT/CNC & 4.363 & 0.5025 & 0.367 & 0.517 \\
A-CNT/CNC & 4.812 & 0.5909 & 0.44 & 1.252 \\
K-CNT/CNC & 5.092 & 0.5592 & 0.04747 & 1.352 \\
\hline
\end{tabular}

\section{Conclusions}

In this work, pristine MWCNTs, MWCNTs chemically treated using acidic/basic agents, and MWCNTs with CNCs added-acting as counter electrodes in DSSCs-were compared to evaluate their photovoltaic performances. The chemically functionalized CNTs and those with CNCs added demonstrated significantly improved dispersion in solution. The highest dispersion was observed for K-CNT + CNC, i.e., CNT subjected to basic treatment followed by the addition of CNC. From the electrical conductivity data of the various CNTs, it was confirmed that the trend of electrical conductivity was similar to that of dispersion. Therefore, alkaline treatment and addition of CNCs was found to be an effective way to increase dispersion and electrical conductivity. In terms of chemical processes, the mild alkaline oxidation process was found to be a more effective, environmentally-friendly, and convenient method for the functionalization of CNTs, without using any organic solvents or strong acids. The energy-conversion efficiencies of the samples also showed a trend similar to that of the dispersion and electrical conductivity. The pristine MWCNT showed the lowest efficiency, $0.2 \%$, whereas K-CNT + CNC showed the highest efficiency, $1.35 \%$. The photovoltaic performance showed the same trend as the energy conversion efficiency. The main aim of this research was to compare the photovoltaic performance of different MWCNTs with different chemical treatments and added dispersants. The conversion efficiencies of these samples were low compared to the general conversion efficiency of DSSCs, because proper conditions for photoanodes with N719 dye and triiodide/iodide electrolyte could not be used together with typical Pt-based counter electrodes, as our focus was not on maximizing the efficiency. If proper photoanodes are used, we expect that the efficiency will be comparable to, or better than, the general DSSC efficiencies. This can be tested in a future study.

Author Contributions: Conceptualization, S.K. and J.-T.P.; Data Curation, S.K. and O.D.; Formal Analysis, H.J. and J.-T.P.; Methodology, H.J. and S.-H.C.; Investigation, S.K.; Validation, S.-H.C.; Writing-Original Draft Preparation, S.K.; Writing-Review and Editing, H.J. and J.-T.P.

Funding: This research was funded by Basic Science Research Program through the National Research Foundation of Korea (NRF) funded by the Ministry of Science, ICT and future Planning (No. 2017R1A2B4007620).

Conflicts of Interest: The authors declare no conflicts of interest.

\section{References}

1. O'Regan, B.; Grätzel, M. A low-cost, high-efficiency solar cell based on dye-sensitized colloidal $\mathrm{TiO}_{2}$ films. Nature 1991, 353, 737-740.

2. Nazeeruddin, M.K.; Kay, A.; Rodicio, I.; Humphry-Baker, R.; Müller, E.; Liska, P.; Vlachopoulos, N.; Grätzel, M. Conversion of light to electricity by cis- $\mathrm{X}_{2}$ bis(2,2'-bipyridyl-4,4'-dicarboxylate)ruthenium(II) charge-transfer sensitizers $\left(\mathrm{X}=\mathrm{Cl}^{-}, \mathrm{Br}^{-}, \mathrm{I}^{-}, \mathrm{CN}^{-}\right.$, and $\left.\mathrm{SCN}^{-}\right)$on nanocrystalline titanium dioxide electrodes. J. Am. Chem. Soc. 1993, 115, 6382-6390. [CrossRef]

3. Grätzel, M. Photoelectrochemical cells. Nature 2001, 414, 338-344. [CrossRef]

4. Lee, Y.; Chae, J.; Kang, M. Comparison of the photovoltaic efficiency on DSSC for nanometer sized $\mathrm{TiO}_{2}$ using a conventional sol-gel and solvothermal methods. J. Ind. Eng. Chem. 2010, 16, 609-614. [CrossRef]

5. Chappel, S.; Chen, S.G.; Zaban, A. $\mathrm{TiO}_{2}$-coated nanoporous $\mathrm{SnO}_{2}$ electrodes for dye-sensitized solar cells. Langmuir 2002, 18, 3336-3342. [CrossRef] 
6. Bedja, I.; Kamat, P.V.; Hua, X.; Lappin, A.G.; Hotchandani, S. Photosensitization of nanocrystalline ZnO films by bis(2,2'-bipyridine)(2,2'-bipyridine-4,4'-dicarboxylic acid)ruthenium(II). Langmuir 1997, 13, 2398-2408. [CrossRef]

7. Keis, K.; Bauer, C.; Boschloo, G.; Hagfeldt, A.; Westermark, K.; Rensmo, H.; Siegbahn, H. Nanostructured ZnO electrodes for dye-sensitized solar cell applications. J. Photochem. Photobiol. A Chem. 2002, 148, 57-64. [CrossRef]

8. Chappel, S.; Zaban, A. Nanoporous $\mathrm{SnO}_{2}$ electrodes for dye-sensitized solar cells: Improved cell performance by the synthesis of $18 \mathrm{~nm} \mathrm{SnO}_{2}$ colloids. Sol. Energy Mater. Sol. Cells 2002, 71, 141-152. [CrossRef]

9. Guo, P.; Aegerter, M.A. $\mathrm{RU}$ (II) sensitized $\mathrm{Nb}_{2} \mathrm{O}_{5}$ solar cell made by the sol-gel process. Thin Solid Films 1999, 351, 290-294. [CrossRef]

10. Murakami, T.N.; Grätzel, M. Counter electrodes for DSC: Application of functional materials as catalysts. Inorganica Chimica Acta 2008, 361, 572-580. [CrossRef]

11. Congiu, M.; Bonomo, M.; Marco, M.L.D.; Dowling, D.P.; Di Carlo, A.; Dini, D.; Graeff, C.F. Cobalt sulfide as counter electrode in p-type dye-sensitized solar cells. ChemistrySelect 2016, 1, 2808-2815. [CrossRef]

12. Zhang, J.; Hao, Y.; Yang, L.; Mohammadi, H.; Vlachopoulos, N.; Sun, L.; Hagfeldt, A. Electrochemically polymerized poly(3,4-phenylenedioxythiophene) as efficient and transparent counter electrode for dye sensitized solar cells. Electrochim. Acta 2019, 300, 482-488. [CrossRef]

13. Hu, L.; Hecht, D.S.; Gruner, G. Carbon nanotube thin films: Fabrication, properties, and applications. Chem. Rev. 2010, 110, 5790-5844. [CrossRef] [PubMed]

14. Dan, B.; Irvin, G.C.; Pasquali, M. Continuous and scalable fabrication of transparent conducting carbon nanotube films. ACS Nano 2009, 3, 835-843. [CrossRef]

15. Hu, L.; Hecht, D.S.; Grüner, G. Percolation in transparent and conducting carbon nanotube networks. Nano Lett. 2004, 4, 2513-2517. [CrossRef]

16. Becerril, H.A.; Mao, J.; Liu, Z.; Stoltenberg, R.M.; Bao, Z.; Chen, Y. Evaluation of solution-processed reduced graphene oxide films as transparent conductors. ACS Nano 2008, 2, 463-470. [CrossRef]

17. Hong, W.; Xu, Y.; Lu, G.; Li, C.; Shi, G. Transparent graphene/PEDOT-PSS composite films as counter-electrodes of dye-sensitized solar cells. Electrochem. Commun. 2008, 10, 1555-1558. [CrossRef]

18. Hu, L.; Hecht, D.S.; Grüner, G. Infrared transparent carbon nanotube thin films. Appl. Phys. Lett. 2009, 94, 081103. [CrossRef]

19. Li, X.; Zhang, G.; Bai, X.; Sun, X.; Wang, X.; Wang, E.; Dai, H. Highly conducting graphene sheets and Langmuir-Blodgett films. Nat. Nanotechnol. 2008, 3, 538-542. [CrossRef]

20. Meyer, J.C.; Geim, A.K.; Katsnelson, M.I.; Novoselov, K.S.; Booth, T.J.; Roth, S. The structure of suspended graphene sheets. Nature 2007, 446, 60-63. [CrossRef]

21. Son, Y.W.; Cohen, M.L.; Louie, S.G. Energy gaps in graphene nanoribbons. Phys. Rev. Lett. 2006, 97, 216803. [CrossRef]

22. Wang, X.; Zhi, L.J.; Mullen, K. Transparent, conductive graphene electrodes for dye-sensitized solar cells. Nano Lett. 2008, 8, 323-327. [CrossRef]

23. Wu, J.B.; Becerril, H.A.; Bao, Z.N.; Liu, Z.F.; Chen, Y.S.; Peumans, P. Organic solar cells with solution-processed graphene transparent electrodes. Appl. Phys. Lett. 2008, 92, 263302. [CrossRef]

24. Ju, S.; Li, J.F.; Liu, J.; Chen, P.C.; Ha, Y.G.; Ishikawa, F.; Chang, H.; Zhou, C.W.; Facchetti, A.; Janes, D.B.; et al. Transparent active matrix organic light-emitting diode displays driven by nanowire transistor circuitry. Nano Lett. 2008, 8, 997-1004. [CrossRef] [PubMed]

25. De, S.; Higgins, T.M.; Lyons, P.E.; Doherty, E.M.; Nirmalraj, P.N.; Blau, W.J.; Boland, J.J.; Coleman, J.N. Silver nanowire networks as flexible, transparent, conducting films: extremely high DC to optical conductivity ratios. ACS Nano 2009, 3, 1767-1774. [CrossRef]

26. Tung, V.C.; Allen, M.J.; Yang, Y.; Kaner, R.B. High-throughput solution processing of large-scale graphene. Nat. Nanotechnol. 2009, 4, 25-29. [CrossRef] [PubMed]

27. Tung, V.C.; Chen, L.M.; Allen, M.J.; Wassei, J.K.; Nelson, K.; Kaner, R.B.; Yang, Y. Low-temperature solution processing of graphene-carbon nanotube hybrid materials for high-performance transparent conductors. Nano Lett. 2009, 9, 1949-1955. [CrossRef] [PubMed]

28. Ma, L.; Kang, J.; Liu, Y.; He, H. Economical and highly efficient Pt-free counter electrode for dye-sensitized solar cells. Colloids Surf. A Physicochem. Eng. Asp. 2019, 566, 1-10. [CrossRef] 
29. Lee, S.U.; Choi, W.S.; Hong, B. A comparative study of dye-sensitized solar cells added carbon nanotubes to electrolyte and counter electrodes. Sol. Energy Mater. Sol. Cells 2010, 94, 680-685. [CrossRef]

30. Luo, J.; Niu, H.J.; Wu, W.J.; Wang, C.; Bai, X.D.; Wang, W. Enhancement of the efficiency of dye-sensitized solar cell with multi-wall carbon nanotubes/polythiophene composite counter electrodes prepared by electrodeposition. Solid State Sci. 2012, 14, 145-149. [CrossRef]

31. Wu, J.; Lan, Z.; Lin, J.; Huang, M.; Huang, Y.; Fan, L.; Luo, G. Electrolytes in dye-sensitized solar cells. Chem. Rev. 2015, 115, 2136-2173. [CrossRef]

32. Mohanty, S.P.; Bhargava, P. Impact of electrolytes based on different solvents on thelong term stability of dye sensitized solar cells. Electrochim. Acta 2015, 168, 111-115. [CrossRef]

33. Nguyen, P.T.; Nguyen, T.D.T.; Nguyen, V.S.; Dang, D.T.X.; Le, H.M.; Wei, T.C.; Tran, P.H. Application of deep eutectic solvent from phenol and choline chloride in electrolyte to improve stability performance in dye-sensitized solar cells. J. Mol. Liq. 2019, 277, 157-162. [CrossRef]

34. Datsyuk, V.; Kalyva, M.; Papagelis, K.; Parthenios, J.; Tasis, D.; Siokou, A.; Kallitsis, A.; Galiotis, C. Chemical oxidation of multiwalled carbon nanotubes. Carbon 2008, 46, 833-840. [CrossRef]

35. Datye, A.; Wu, K.H.; Gomes, G.; Monroy, V.; Lin, H.T.; Jozef, V.; Vanmeensel, K. Synthesis, microstructure and mechanical properties of Yttria Stabilized Zirconia (3YTZP)—Multi-Walled Nanotube (MWNTs) nanocomposite by direct in-situ growth of MWNTs on Zirconia particles. Compos. Sci. Technol. 2010, 70, 2086-2092. [CrossRef]

36. Lee, K.M.; Hu, C.W.; Chen, H.W.; Ho, K.C. Incorporating carbon nanotube in a low-temperature fabrication process for dye-sensitized $\mathrm{TiO}_{2}$ solar cells. Sol. Energy Mater. Sol. Cells 2008, 92, 1628-1633. [CrossRef]

37. Park, O.K.; Jeevananda, T.; Kim, N.H.; Kim, S.I.; Lee, J.H. Effects of surface modification on the dispersion and electrical conductivity of carbon nanotube/polyaniline composites. Scr. Mater. 2009, 60, 551-554. [CrossRef]

38. Choi, H.J.; Shin, J.E.; Lee, G.W.; Park, N.G.; Kim, K.; Hong, S.C. Effect of surface modification of multi-walled carbon nanotubes on the fabrication and performance of carbon nanotube based counter electrodes for dye-sensitized solar cells. Curr. Appl. Phys. 2010, 10, S165-S167. [CrossRef]

39. Ramasamy, E.; Lee, W.J.; Lee, D.Y.; Song, J.S. Spray coated multi-wall carbon nanotube counter electrode for tri-iodide $\left(\mathrm{I}_{3}{ }^{-}\right)$reduction in dye-sensitized solar cells. Electrochem. Commun. 2008, 10, 1087-1089. [CrossRef]

40. Lee, W.J.; Ramasamy, E.; Lee, D.Y.; Song, J.S. Efficient dye-sensitized solar cells with catalytic multiwall carbon nanotube counter electrodes. Appl. Mater. Interfaces 2009, 1, 1145-1149. [CrossRef]

41. Nam, J.G.; Park, Y.J.; Kim, B.S.; Lee, J.S. Enhancement of the efficiency of dye-sensitized solar cell by utilizing carbon nanotube counter electrode. Scr. Mater. 2010, 62, 148-150. [CrossRef]

42. Ramachandran, K.; Kadirgama, K.; Ramasamy, D.; Azmi, W.H.; Tarlochan, F. Investigation on effect thermal conductivity and relative viscosity of cellulose nanocrystal as a nanofluidic thermal transport through a combined experimental—Statistical approach by using response surface methodology. Appl. Therm. Eng. 2017, 122, 473-483. [CrossRef]

43. Ramachandran, K.; Hussein, A.M.; Kadirgama, K.; Ramasamy, D.; Azmi, W.H.; Tarlochan, F.; Kadirgama, G. Thermophysical properties measurement of nano cellulose in ethylene glycol/water. Appl. Therm. Eng. 2017, 123, 1158-1165. [CrossRef]

44. Myekhlai, M.; Munkhbayar, B.; Lee, T.; Tanshen, M.R.; Chung, H.; Jeong, H. Experimental investigation of the mechanical grinding effect on graphene structure. RSC Adv. 2014, 4, 2495-2500. [CrossRef]

45. Munkhbayar, B.; Nine, M.J.; Jeoun, J.; Bat-Erdene, M.; Chung, H.; Jeong, H. Influence of dry and wet ball milling on dispersion characteristics of the multi-walled carbon nanotubes in aqueous solution with and without surfactant. Powder Technol. 2013, 234, 132-140. [CrossRef]

46. Hong, C.E.; Lee, J.H.; Kalappa, P.; Advani, S.G. Effects of oxidative conditions on properties of multi-walled carbon nanotubes in polymer nanocomposites. Compos. Sci. Technol. 2007, 67, 1027-1034. [CrossRef]

47. Zhang, L.; Ni, Q.Q.; Fu, Y.; Natsuki, T. One-step preparation of water-soluble single-walled carbon nanotubes. Appl. Surf. Sci. 2009, 255, 7095-7099. [CrossRef]

48. Munkhbayar, B.; Hwang, S.; Kim, J.; Bae, K.; Ji, M.; Chung, H.; Jeong, H. Photovoltaic performance of dye-sensitized solar cells with various MWCNT counter electrode structures produced by different coating methods. Electrochim. Acta 2012, 80, 100-107. [CrossRef]

49. Dhungel, S.K.; Park, J.G. Optimization of paste formulation for $\mathrm{TiO}_{2}$ nanoparticles with wide range of size distribution for its application in dye sensitized solar cells. Renew. Energy 2010, 35, 2776-2780. [CrossRef] 
50. Tsoukleris, D.S.; Arabatzis, I.M.; Chatzivasiloglou, E.; Kontos, A.I.; Belessi, V.; Bernard, M.C.; Falaras, P. 2-Ethyl-1-hexanol based screen-printed titania thin films for dye-sensitized solar cells. Sol. Energy. 2005, 79, 422-430. [CrossRef]

51. Jhong, H.R.; Wong, D.S.H.; Wan, C.C.; Wang, Y.Y.; Wei, T.C. A novel deep eutectic solvent-based ionic liquid used as electrolyte for dye-sensitized solar cells. Electrochem. Commun. 2009, 11, 209-211. [CrossRef]

52. Yudianti, R.; Onggo, H.; Saito, Y.; Iwata, T.; Azuma, J.I. Analysis of functional group sited on multi-wall carbon nanotube surface. Open Mater. Sci. J. 2011, 5, 242-247. [CrossRef]

53. Ni, Z.; Wang, Y.; Yu, T.; Shen, Z. Raman spectroscopy and imaging of graphene. Nano Res. 2008, 1, $273-291$. [CrossRef]

54. Gupta, A.; Chen, G.; Joshi, P.; Tadigadapa, S.; Eklund, P.C. Raman scattering from high-frequency phonons in supported n-graphene layer films. Nano Lett. 2006, 6, 2667-2673. [CrossRef]

55. Graf, D.; Molitor, F.; Ensslin, K.; Stampfer, C.; Jungen, A.; Hierold, C.; Wirtz, L. Spatially resolved Raman spectroscopy of single- and few-layer graphene. Nano Lett. 2007, 7, 238-242. [CrossRef]

56. Wang, X.; Huang, P.; Feng, L.; He, M.; Guo, S.; Shen, G.; Cui, D. Green controllable synthesis of silver nanomaterials on graphene oxide sheets via spontaneous reduction. RSC Adv. 2012, 2, 3816-3822. [CrossRef]

57. Yoo, H.J.; Kim, K.H.; Yadav, S.K.; Cho, J.W. Effects of carbon nanotube functionalization and annealing on crystallization and mechanical properties of melt-spun carbon nanotubes/poly(ethylene terephthalate) fibers. Compos. Sci. Technol. 2012, 72, 1834-1840. [CrossRef]

58. Munkhbayar, B.; Bat-Erdene, M.; Ochirkhuyag, B.; Sarangerel, D.; Battsengel, B.; Chung, H.; Jeong, H. An experimental study of the planetary ball milling effect on dispersibility and thermal conductivity of MWCNTs-based aqueous nanofluids. Mater. Res. Bull. 2012, 47, 4187-4196. [CrossRef]

59. Shim, J.W.; Park, S.J.; Ryu, S.K. Effect of modification with $\mathrm{HNO}_{3}$ and $\mathrm{NaOH}$ on metal adsorption by pitch-based activated carbon fibers. Carbon. 2001, 39, 1635-1642. [CrossRef]

60. Nasiri, A.; Shariaty-Niasar, M.; Rashidi, A.M.; Khodafarin, R. Effect of CNT structures on thermal conductivity and stability of nanofluid. Inter. J. Heat Mass Transf. 2012, 55, 1529-1535. [CrossRef]

61. Yadav, S.K.; Mahapatra, S.S.; Yoo, H.J.; Cho, J.W. Synthesis of multi-walled carbon nanotube/polyhedral oligomeric silsesquioxane nanohybrid by utilizing click chemistry. Nanoscale Res. Lett. 2011, 6, 122. [CrossRef]

62. Wei, J.; Lv, R.; Guo, N.; Wang, H.; Bai, X.; Mathkar, A.; Kang, F.; Zhu, H.; Wang, K.; Wu, D.; et al. Preparation of highly oxidized nitrogen-doped carbon nanotubes. Nanotechnology 2012, 23, 155601. [CrossRef] [PubMed]

63. Gupta, V.K.; Agarwal, S.; Saleh, T.A. Synthesis and characterization of alumina-coated carbon nanotubes and their application for lead removal. J. Hazard. Mater. 2011, 185, 17-23. [CrossRef] [PubMed]

64. Yu, J.; Grossiord, N.; Koning, C.E.; Loos, J. Controlling the dispersion of multi-wall carbon nanotubes in aqueous surfactant solution. Carbon 2007, 45, 618-623. [CrossRef]

65. Hamada, N.; Sawada, S.I.; Oshiyama, A. New one-dimensional conductors: Graphitic microtubules. Phys. Rev. Lett. 1992, 68, 1579. [CrossRef]

66. Saito, R.; Fujita, M.; Dresselhaus, G.; Dresselhaus, U.M. Electronic structure of chiral graphene tubules. Appl. Phys. Lett. 1992, 60, 2204-2206. [CrossRef]

67. Bordi, F.; Cametti, C.; Codastefano, P.; Tartaglia, P. Electrical conductivity of colloidal systems during irreversible aggregation. Phys. A Stat. Mech. Appl. 1990, 164, 663-672. [CrossRef]

(C) 2019 by the authors. Licensee MDPI, Basel, Switzerland. This article is an open access article distributed under the terms and conditions of the Creative Commons Attribution (CC BY) license (http://creativecommons.org/licenses/by/4.0/). 